\title{
The Application of Cluster Analysis for the Selection of Key Competences of Future-Oriented Entrepreneurs
}

\author{
Alicja Ewa Gudanowska ${ }^{1}$, Anna Kononiuk², Katarzyna Debkowska ${ }^{3}$ \\ 1, 2 Faculty of Engineering Management, Bialystok University of Technology \\ Wiejska 45A, 15-351 Bialystok, Poland \\ E-mail.a.gudanowska@pb.edu.pl; a.kononiuk@pb.edu.pl \\ ${ }^{3}$ Polish Economic Institute \\ Al. Jerozolimskie 87,02-001 Warszawa, Poland \\ E-mail.katarzyna.debkowska@pie.net.pl
}

cross $^{\text {ref }}$ http://dx.doi.org/10.5755/j01.ee.31.5.25194

Trends and megatrends affecting the labour market are changing rapidly. Inevitable changes force a permanent need to redefine employees' competences in order to meet employers' expectations The scientific problem raised by the authors of the article is defining a methodology of identifying competences of future-oriented entrepreneurs. The aim of the article is to present the potential of cluster analysis for the selection of key competences of future-oriented entrepreneurs in the context of foresight research. The main research methods applied for this study were literature review and cluster analysis. Literature review covered global literature review, domestic literature review, higher education offer review, commercial foresight courses review as well as case studies. Both extensive literature review and the analysis of business practices allowed to identify more than one thousand six hundred competences of a future-oriented entrepreneur. The huge amount of competences were then the subject to preliminary assessment which resulted in the list of 39 items. The application of cluster analysis enabled to further reduce the number of competences. Finally, seven competences to be mastered by future-oriented entrepreneurs could be recommended such as, but not limited to: the ability to find and interpret weak signals of change and disruptions (wild cards and abnormal phenomena); the ability to act proactively; the ability to manage change and uncertainty; the ability to run strategic foresight within organization, the ability to create organizational vision (both collective and individual); and seeing the big picture .

Keywords: Cluster Analysis; Competences; Competence Selection; Future-Oriented Entrepreneur, Future Thinking.

\section{Introduction}

The factors determining the contemporary labour market are changing very quickly. Genetics, robotics, nanotechnology, new business models, aging society, but also new customer demands and shorter production cycles significantly affect the nature of work and employers' expectations. Today's and tomorrow's relevant competences may prove inadequate to meet the challenges faced by workers in a globalised labour market dominated by new technologies (McGuiness et al., 2017; Bolinska et al., 2019; Roztocki \& Narcyz 2015; Insights into skill shortages and skill mismatch: learning from Cedefop's European skills and jobs survey, 2018)

The scientific problem raised by the authors of the article is defining a methodology of identifying the competences of future-oriented entrepreneurs. The aim of the article is to present the possibilities of application of cluster analysis for the selection of key competences of future-oriented entrepreneurs on the basis of data collected within "Becoming Future-Oriented Entrepreneurs in universities and companies - beFORE" project, in which the authors of the paper took part. Initiative is funded under the Erasmus + Knowledge Alliance scheme. The project involved ten partners (universities and companies) representing four countries such as Poland, Italy, Germany and Spain. The project has been coordinated by Lukasiewicz Research Network - The Institute for Sustainable Technologies located in Poland. The goal of beFORE project was to increase future literacy among students, academics and entrepreneurs as well as to guide individuals and organisations in their future preparedness. The identified by the researchers competences - on the basis of the literature review and the extensive analysis of case studies in which foresight research was applied - were evaluated by renown foresight experts and project partners with regard to their importance for six dimensions called: a future-oriented entrepreneur, insight, visioning strategy development, innovating and leadership with the application of 5-point Likert scale. Finally, the authors of the article, recommend 7 competences of strategic foresight to be mastered by futureoriented entrepreneurs.

\section{Theoretical Framework and Research Method}

Competences have been an issue of interest in scientific literature since the beginning of the 20th century (Volpentesta \& Felicetti, 2011). There are many ways to understand the notion "competence". Often the terms competence, skills, qualifications, rights and duties are used interchangeably. In reality, however, these are not the same concepts. Clear distinction between competences, knowledge 
and skills is often also problematic (Kinkel et al., 2017). According to Hertle and others, knowledge is the narrowest concept, including certain abilities. Qualifications take precedence over knowledge and competences cover the other two terms (Hertle et al., 2015). Competence can therefore be understood as the relationship between a person and the tasks to be carried out in the course of a professional career, i.e. the knowledge and skills required to carry out a specific task effectively (Volpentesta \& Felicetti, 2011). Competences also have certain essential characteristics: they are related to a specific task or professional activity; they are variable and therefore subject to development; they change with experience and professional and life development; they are measurable (Kubat \& Filipowicz, 2016; Gudanowska et al., 2018).

The literature shows a trend related to the search for appropriate competences that should characterise an educated entrepreneur (Gonzalez \& Kobylinska, 2019) so that one can successfully (Jain, 2011; Lewrick et al., 2010) and in a sustainable way (Coyne, 2016) carry out his work. Already in the $80 \mathrm{~s}$, Ronstadt pointed out that entrepreneurship and related competences can and must be mastered (Ronstadt, 1987). It is also important to realize that these are competences different from those assigned to general managerial competences (Morris et al., 2013). However, despite the discussions in the literature on understanding competences of future-oriented entrepreneurs, it is important to search for competences that allow to adapt to the requirements of the contemporary market, especially in the context of competences related to creativity and innovation (Edwards-Schachtera et al., 2015).

Among the important competences of entrepreneurs are those related to anticipation, intuition and perception of new opportunities. In this context, in comparison with the concepts and approaches presented in the literature, foresight stands out (Mosakowski, 1998). Foresight activities should be part of the toolkit for entrepreneurship (Gheorghiua et al., 2016). Also in the context of corporate social responsibility - thinking about the future is one of the important competence areas of a responsible entrepreneur (Osagie et al., 2016).

In a world of fast changes and uncertainty, futures literate individuals will increase their employability, as suggested in the 2006 European Reference Framework for Key Competences for Lifelong Learning: the challenge lies on how to provide an entrepreneurship education that offers competences matching the characteristics of the current state of the world: i) rapid technological and organizational change and need for innovation (Kononiuk, Sacio-Szymanska \& Gaspar, 2017); ii) "information overload/pollution" (Levitin, 2014); iii)“weak signals" (Kuusi \& Hiltunen, 2011).

Based on a survey conducted among a large group of directors and senior managers, van der Laan and Erwee indicate that foresight is a cognitive disposition and they highlight the importance of foresight in the context of leadership (van der Laan \& Erwee 2012). Foresight may affect both individual and organizational learning (Baskarada et al., 2016). Future-oriented thinking is the core competence because it is the foundation for imagination, strategy development and the creation of a preferred future in organizations (Inayatullah, 2008). Grimm provides organizations with a useful Foresight Maturity Model (FMM) that allows organizations to identify best practices in foresight and measure their practices (Grimm, 2009; Kononiuk, 2014).

Thinking about the future and knowing how to use appropriate methods related to analysing and anticipating the future should be an important element of education in business schools (Ratcliffe \& Ratcliffe 2015), which will raise future-oriented entrepreneurs. An interesting view on competences of future-oriented entrepreneurs is presented by Heinonen and Ruotsalainen (2012). According to the authors, in a holistic, creative, and meaning-based neogrowth of economy, general competences and skills are especially needed. Instead of high specialization, multiple competences will become critical in future work. The workforce will be utilizing the whole range of the human potentials and skills more and more. Soft competences i.e., skills of communication, interaction, and socio-cultural sensemaking will, in particular, gain in importance. The following set of future skills and competences are summarized in the concept of the Futures Competences Diamond, consisting of seven edges (Heinonen, 2012) including the following competences of the future-oriented entrepreneur: interaction competence, collaboration competence, time competence, technology competence, environmental competence and systems competence.

The main research methods applied for this study were literature review and cluster analysis. Literature review covered global literature review, domestic literature review, higher education offer review, commercial foresight courses review and case studies. Case studies enable to identify competences of future-oriented entrepreneur retrieved from well documented 52 business practices. Both extensive literature review and the analysis of business practices allowed to identify more than one thousand six hundred competences of a future-oriented entrepreneur. The huge amount of competences, their heterogenity and a different level of granularity presented a major challenge for the researchers. The competences were then the subject to preliminary assessement. The limited set of competences (39 items) was a subject to cluster analysis.

Cluster analysis is a method of grouping that allows for the identification of groups containing similar objects (Tryon, 1939). Clustering techniques are used in many different research fields. A perfect summary of many published studies that inform the reader about the results of the analysis of clusters is provided by Hartigan (Hartigan, 1975). This method is representative of the so-called methods of analysis of interdependence, which means that all variables in the analysis are treated as interdependent without distinguishing between dependent (effects) and independent variables (causes). The purpose of the analysis in such a case is usually to identify the structure of the examined set of variables or objects. Cluster analysis as a method of grouping allows for the identification of internally consistent groups of objects.

\section{Data Collection and Research Process}

All in all, out of 193 sources, (global and domestic literature review: 71, syllabuses: 53, foresight courses: 17, 
business foresight practices: 52) there were identified the extensive set of competences consisting of 1626 items. As the set of competences was very extensive and two stages of grouping were proposed: stage I - preliminary and stage II basic.

First stage manifested in the initial overview of the 1626 competences and assigning them to the one of the 12 working spheres such as: insight, framing, creativity, personal, leadership, implementing, strategy, innovation, visioning, theory\&methods, general knowledge, nowhere else. The names of the clusters were retrieved on the basis on the experts intuition as well as foresight models and stages already existing in the literature, such as Foresight Competency Model; APF 2016; and other foresight conceptual frameworks posited by Habegger (2010); Miles and Popper (2008) and Magruk (2014). The identification of the working spheres helped the researchers to capture the whole range of competences and then further group them within the working groups.

Second stage manifested in the detailed analysis of each of the competences and the final assigning them to the thematic area. The same competences (and the similar ones) were grouped under subgroups. If there appeared some of the competences that were not clear in meaning or the competences not necessarily linked with the thematic scope of the course, they were assigned to the "nowhere else" group. As the scope of the project was more on the competences of an entrepreneur stemming from knowledge and skills area, "personal competences" and "nowhere else" cluster of the competences were excluded from the analysis. Furthermore, these competences were not futureoriented and very general in nature. The clusters mentioned above embraced such competences as assertiveness, need for autonomy, tolerance, management skills, to name but a few. After the rejection of "personal competences" and "nowhere else competences", the group comprised 50 working clusters of the competences. Then, a further analysis of 50 working clusters was carried out. The initial list of 50 clusters was juxtaposed with results of the literature review of well-established published works on competences (Spencer \& Spencer 1993; Boyatzis 1982; Bird 1995; Chandler \& Jansen 1992). The results of the juxtaposition were discussed and further analysed by the authors of the article and finally the list of 50 clusters was further reduced to 39 competences, which were subject to internal assessment (table 1).

Table 1

Competences of a Future-Oriented Entrepreneur

\begin{tabular}{|c|c|}
\hline Symbol & Competency \\
\hline C_1 & $\begin{array}{l}\text { the ability to define, identify and analyze trends within micro- } \\
\text { and macroenvironment of the company }\end{array}$ \\
\hline C_2 & $\begin{array}{l}\text { the ability to find and interpret weak signals of change and } \\
\text { disruptions (wild cards and abnormal phenomena) }\end{array}$ \\
\hline C_3 & $\begin{array}{l}\text { the ability to identify factors influencing the use of strategic } \\
\text { foresight by companies }\end{array}$ \\
\hline C_4 & $\begin{array}{l}\text { the ability to define measurable goals to create preferred } \\
\text { future vision for the organization }\end{array}$ \\
\hline C_5 & the ability to work in teams \\
\hline C_6 & the ability to possess querilla skills to challenge assumptions \\
\hline C_7 & $\begin{array}{l}\text { the ability to gather, analyze process and interpret data (also } \\
\text { using it tools) }\end{array}$ \\
\hline C_8 & $\begin{array}{l}\text { the ability to act proactively (autonomous strategic behavior, } \\
\text { enterprising spirit) }\end{array}$ \\
\hline C_9 & reflexive capacity \\
\hline
\end{tabular}

\begin{tabular}{|c|c|}
\hline Symbol & Competency \\
\hline C_10 & $\begin{array}{l}\text { the ability to develop measurement system to control } \\
\text { innovation initiatives and strategic direction }\end{array}$ \\
\hline C_11 & coaching skills \\
\hline C_12 & $\begin{array}{l}\text { the ability to communicate internally, interdisciplinary and } \\
\text { with stakeholders }\end{array}$ \\
\hline C_13 & the ability to manage projects \\
\hline C_1 14 & the ability to develop organizational resilience \\
\hline C_15 & the ability to run strategic foresight within organization \\
\hline C_16 & systemic thinking \\
\hline C_17 & risk-taking capability \\
\hline C_18 & $\begin{array}{l}\text { the ability to manage change and uncertainty (also dynamic } \\
\text { capability) }\end{array}$ \\
\hline C_19 & the ability to build networks both internally and externally \\
\hline C_20 & the ability to deal with complexity \\
\hline C_21 & understanding dangers of efficiency \\
\hline C_22 & the ability to develop and implement strategies \\
\hline C_23 & $\begin{array}{l}\text { time competence (time-organizing skills, utilizing real-time, } \\
\text { making optimal use of the diversities of time, appreciation of } \\
\text { slow life, developing futures thinking, and futures } \\
\text { consciousness) }\end{array}$ \\
\hline C_24 & the ability to think out of the box \\
\hline C_25 & the ability to transform new ideas into business practice \\
\hline C_26 & capacity for design thinking \\
\hline C_27 & $\begin{array}{l}\text { the ability to implement scenario approach within } \\
\text { organization }\end{array}$ \\
\hline C_28 & $\begin{array}{l}\text { the ability to create organizational vision (both collective and } \\
\text { individual) }\end{array}$ \\
\hline C_29 & the ability to identify goods or services people want \\
\hline C_30 & accepting incompleteness of knowledge \\
\hline C_31 & non-linear thinking \\
\hline C_32 & the ability to apply various future studies methodologies \\
\hline C_33 & $\begin{array}{l}\text { the ability to implement selected methods of technology } \\
\text { management (technology assessment, technology mapping, } \\
\text { technology life cycle, prioritetisation, technology audit and } \\
\text { roadmapping) }\end{array}$ \\
\hline C_34 & the ability to perceive unmet consumer needs \\
\hline C_35 & the ability to look for products that provide real benefit \\
\hline C_36 & seizing high-quality business opportunities \\
\hline C_37 & maximizing results in resource allocation \\
\hline C_38 & seeing the big picture \\
\hline C_39 & tolerance of ambiguity \\
\hline
\end{tabular}

(source: Authors' own Study)

Finally, 23 renown foresight experts took part in the internal assessment of 39 competences of a future-oriented entrepreneurs as well as the domains of his/her activity such as: insight, visioning, strategy development, innovating and leadership. The definitions of the domains were as follows:

- insight - interpreting and responding to the present, assessing state of the art of factors shaping business activity;

- visioning - developing a vision for the company's future (both collective and individual);

- strategy developement- a plan of action designed to achieve a long-term goal, capable of being changed in response to shifting market dynamics;

- innovating - applying new ideas to produce a tangible business result such as a new product, service, or process;

- leadership - leading a group of people within organization, establishing a clear vision, sharing it with the employees and stakeholders, coordinating and balancing the conflicting interests of employees and stakeholders.

The domains of a future-oriented entrepreneur activity were defined by the authors of the article on the basis of Foresight Maturity Model posited by Grimm (Grimm 2009). The model takes into consideration such aspects as 
the following: leadership, framing, vision building, planning, scanning and forecasting. The authors of the article decided to get rid of the framing dimension as its definition in the original model is quite vague and include it into strategy development in terms of achieving the goals of the company. This domain includes also planning. Forecasting dimension from the Grimm FMM model was assigned to vision building suggested by the authors of the article. Moreover, the authors of the article decided to add new dimension, namely innovating. Running innovative activities by future-oriented managers is widely recommended in the existing published works on the interconnection between entrepreneurship and innovation (Cooper \& Vlaskovits 2013; Gheorghiua et.al., 2016; Mosakowski, 1998; Rohrbeck, 2010).

The measurement tool was a 5-point Likert's scale where 1 meant that the competence is not very important, whereas 5 meant that a given competence is very important both for a future-oriented entrepreneur or the domains of his/her activity.

\section{Results of the Research}

The obtained results enabled to calculate arithmetic mean values of the assessment of the 39 competences in the given dimensions. In this way, a set consisting of $\mathrm{N}=39$ cases and six variables was obtained (table 2). On the basis of the collected data, the authors created rankings of the competences importance for a future-oriented entrepreneur and domains of his/her activity. From the perspective of the prepared rankings, the most important competences for future oriented manager were: the abilities to transform new ideas into business practice (C_25), to manage change and uncertainty (also dynamic capability) (C_18), to run strategic foresight within organization $\left(\mathrm{C}_{-} 15\right)$ and seeing the big picture (C_38) - arithmetic mean for the assessment obtained above 4,5. The most important from the perspective of the insight dimension was the ability to gather, analyze process and interpret data (also using it tools) ( $\mathrm{C}_{-} 7$ - in this case it was the highest average obtained in this dimension - 4,26), in turn for the visioning dimension the ability to think out of the box (C_24) and to create organizational vision (both collective and individual) (C_28). However, from the perspective of strategic development dimensions, the most important ones turned out to be the ability to develop and implement strategies (C_22). For the dimension innovating it was the ability to think out of the box (C_24) and for the dimension leadership it was the ability to communicate internally, interdisciplinary and with stakeholders $\left(\mathrm{C}_{-} 12\right)$.

In table 2, assessments of the competences evaluated as important (arithmetic average $>=4$ ) both for a futureoriented entrepreneur and domains of his/her activity were distinguished.
Arithmetic Mean Values for the Assessment of 39 Competences

\begin{tabular}{|c|c|c|c|c|c|c|}
\hline \multirow[b]{2}{*}{ 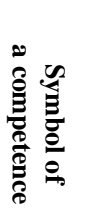 } & \multicolumn{6}{|c|}{ Importance of a competence } \\
\hline & 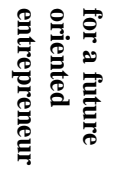 & 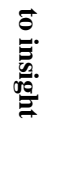 & $\begin{array}{l}\text { s. } \\
\text { s. } \\
\text { : } \\
\text { : } \\
\text { : }\end{array}$ & 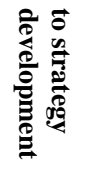 & 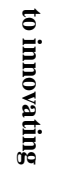 & 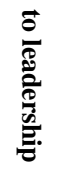 \\
\hline C_1 & 4,48 & 3,96 & 4,30 & 4,39 & 3,70 & 2,91 \\
\hline C_2 & 4,43 & 3,96 & 4,48 & 4,09 & 4,13 & 3,22 \\
\hline C_3 & 3,61 & 3,39 & 3,43 & 3,48 & 2,74 & 2,83 \\
\hline C_4 & 4,22 & 3,22 & 3,96 & 4,30 & 3,30 & 4,00 \\
\hline C_5 & 4,13 & 3,17 & 3,17 & 3,83 & 4,30 & 4,48 \\
\hline C_6 & 4,04 & 3,52 & 3,87 & 3,61 & 4,22 & 3,57 \\
\hline C_7 & 4,13 & 4,26 & 3,74 & 4,17 & 3,65 & 3,26 \\
\hline C__8 & 4,35 & 3,43 & 4,13 & 4,13 & 4,09 & 4,35 \\
\hline C_-9 & 4,17 & 4,13 & 3,96 & 4,09 & 3,78 & 3,57 \\
\hline C_10 & 3,57 & 3,17 & 2,96 & 3,96 & 3,87 & 3,35 \\
\hline C_11 & 3,30 & 2,43 & 2,52 & 2,61 & 2,96 & 4,35 \\
\hline C_12 & 4,39 & 3,39 & 3,57 & 3,91 & 3,74 & 4,57 \\
\hline C_13 & 4,43 & 3,04 & 2,91 & 3,65 & 3,83 & 4,43 \\
\hline C_14 & 4,13 & 3,22 & 3,17 & 4,09 & 3,87 & 4,00 \\
\hline C_15 & 4,52 & 3,87 & 4,35 & 4,39 & 4,00 & 3,78 \\
\hline C_16 & 4,43 & 3,78 & 3,65 & 4,35 & 3,65 & 3,48 \\
\hline C_17 & 4,26 & 2,87 & 3,61 & 3,74 & 4,30 & 3,83 \\
\hline C_18 & 4,57 & 3,26 & 3,96 & 4,22 & 4,26 & 4,35 \\
\hline C_19 & 4,39 & 3,26 & 3,52 & 3,78 & 3,91 & 4,26 \\
\hline C_20 & 4,35 & 3,91 & 3,96 & 4,13 & 3,87 & 3,78 \\
\hline C_21 & 3,57 & 3,30 & 3,13 & 3,70 & 3,22 & 3,43 \\
\hline C_22 & 4,43 & 3,39 & 3,61 & 4,78 & 3,96 & 4,00 \\
\hline C_23 & 4,39 & 3,26 & 3,26 & 3,74 & 3,26 & 4,13 \\
\hline C_24 & 4,35 & 3,70 & 4,61 & 3,91 & 4,61 & 3,48 \\
\hline C_25 & 4,57 & 3,39 & 3,78 & 4,30 & 4,48 & 3,70 \\
\hline C_26 & 3,78 & 3,00 & 3,57 & 3,83 & 4,26 & 2,91 \\
\hline C_27 & 4,13 & 3,35 & 4,17 & 4,04 & 3,48 & 3,30 \\
\hline C_28 & 4,43 & 3,30 & 4,52 & 4,22 & 3,52 & 4,39 \\
\hline C_29 & 3,87 & 3,48 & 3,83 & 3,78 & 3,96 & 3,43 \\
\hline C_30 & 3,57 & 3,22 & 3,30 & 3,52 & 3,22 & 3,17 \\
\hline C_31 & 4,17 & 3,61 & 4,39 & 3,70 & 4,39 & 3,48 \\
\hline C_32 & 4,04 & 3,70 & 4,09 & 4,13 & 3,65 & 3,43 \\
\hline C_33 & 3,91 & 3,61 & 3,52 & 3,74 & 3,91 & 3,30 \\
\hline C_34 & 4,17 & 3,74 & 4,30 & 4,09 & 4,17 & 3,30 \\
\hline C_35 & 4,09 & 3,57 & 3,61 & 3,87 & 3,87 & 3,17 \\
\hline C_36 & 4,30 & 3,43 & 3,61 & 4,17 & 3,96 & 3,65 \\
\hline C_37 & 3,74 & 3,13 & 3,00 & 3,70 & 3,17 & 3,83 \\
\hline C_38 & 4,52 & 4,17 & 4,48 & 4,39 & 4,13 & 4,04 \\
\hline C_39 & 3,30 & 2,96 & 2,96 & 2,96 & 3,26 & 3,04 \\
\hline
\end{tabular}

(Source: Authors'own study)

In the next stage of the research process, correlations between variables (importance for a future-oriented entrepreneur and domains of his/her activity) were calculated.

All correlation coefficients presented in the table 3 are positive and their values indicate a moderate or strong correlation between assessments of the importance of 
competences for areas and assessments of the importance of competences for a future-oriented entrepreneur. A positive correlation means that with the increase in the importance of competences for domains one could observe an increase in the importance of competences for a future-oriented entrepreneur. In particular, we can distinguish two domains that have the strongest influence on the future-oriented entrepreneur: strategy development (correlation coefficient $=0.758197$ ) and visioning (correlation coefficient $=0.622013$ )

Table 3

The Correlation between the Variables

\begin{tabular}{|c|c|c|c|c|c|}
\hline \multirow{2}{*}{ Variable } & \multicolumn{5}{|c|}{$\begin{array}{l}\text { Correlation coefficient are significant with the } p<0,05 \\
\qquad N=39\end{array}$} \\
\hline & $\begin{array}{c}\text { to } \\
\text { insight }\end{array}$ & \begin{tabular}{|c|} 
to \\
visioning
\end{tabular} & $\begin{array}{c}\text { to strategy } \\
\text { development }\end{array}$ & $\begin{array}{c}\text { to } \\
\text { innovating }\end{array}$ & $\begin{array}{c}\text { to } \\
\text { leadership }\end{array}$ \\
\hline 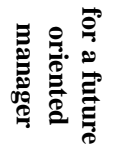 & 0,478338 & 0,622013 & 0,758197 & 0,555754 & 0,406472 \\
\hline
\end{tabular}

(source: Authors'own study)

In the next step of the analysis, the competences were grouped according to the similarity of the assessment in five dimensions with the help of cluster analysis. Objects (competences) were grouped into the groups of objects similarly evaluated according to some variables (in this case: domains). A dendrogram was prepared, on the basis of which four clusters emerged as the first stage of the cluster analysis. Then, for the defined four clusters, with the help of k-means method, the content of each cluster was specified as well as the average marks for the dimensions assessment in the competences clusters. The content of the competences clusters achieved with the help of dendrogram (figure 1) and k-means method was the same (plot of means for each cluster are presented in figure 2).
As a result of cluster analysis, four clusters were obtained. The first one was characterized by the highest scores for the following variables (dimensions): insight $(3,86)$, visioning $(4,19)$, strategy development $(4,14)$ and innovating $(3,94)$. At the same time it was cluster that has obtained very low score for the leadership dimension $(3,46)$. Competences that were included in the cluster are listed in table 4 . The closest to the first cluster center were competences C_2, C_9, C_15, C_20, C_32 and C_34. It means that they were given the most similar marks within the cluster (distance measure $<=0,2$ ). The second cluster was characterized by the low scores for dimension insight $(3,27)$, average scores for dimension visioning $(3,62)$, high scores for dimension strategy development $(4,06)$, a little bit lower but still high scores for dimension innovating $(3,82)$ and very high scores for the dimension leadership $(4,27)$. Competencies from this cluster are listed in table 4 , and among them C_12 and C_19 are the closest to the center of the second cluster. Those two competences were given the most similar marks within the cluster (distance measure $<0,2$ ). The lowest scores in all analyzed dimensions (insight $-3,07$; visioning - 3,06; strategy development $-3,33$; innovating - 3,09 and leadership - 3,44) is a feature of the third cluster. As all of the competences evaluated in the third cluster (table 4) received low scores both for the importance for a future-oriented manager as well as for the domains of his activity. Therefore, on the basis of the cluster analysis results, it was recommended to exclude competences from this cluster from the further analysis. The last - fourth cluster was characterized by the low importance for dimension insight $(3,27)$, average score for dimension visioning $(3,59)$, quite high score for dimension strategy development $(3,89)$, very high score for dimension innovating $(4,09)$ and low score for dimension leadership $(3,43)$. Competencies from this cluster are also listed in table 4 . The closest to the center of this cluster with the most similar marks within the cluster (distance measure < 0,2) were competences C_29, C_33, C_35 and C_36. 
Alicja Ewa Gudanowska, Anna Kononiuk, Katarzyna Debkowska. The Application of Cluster Analysis for the Selection ...

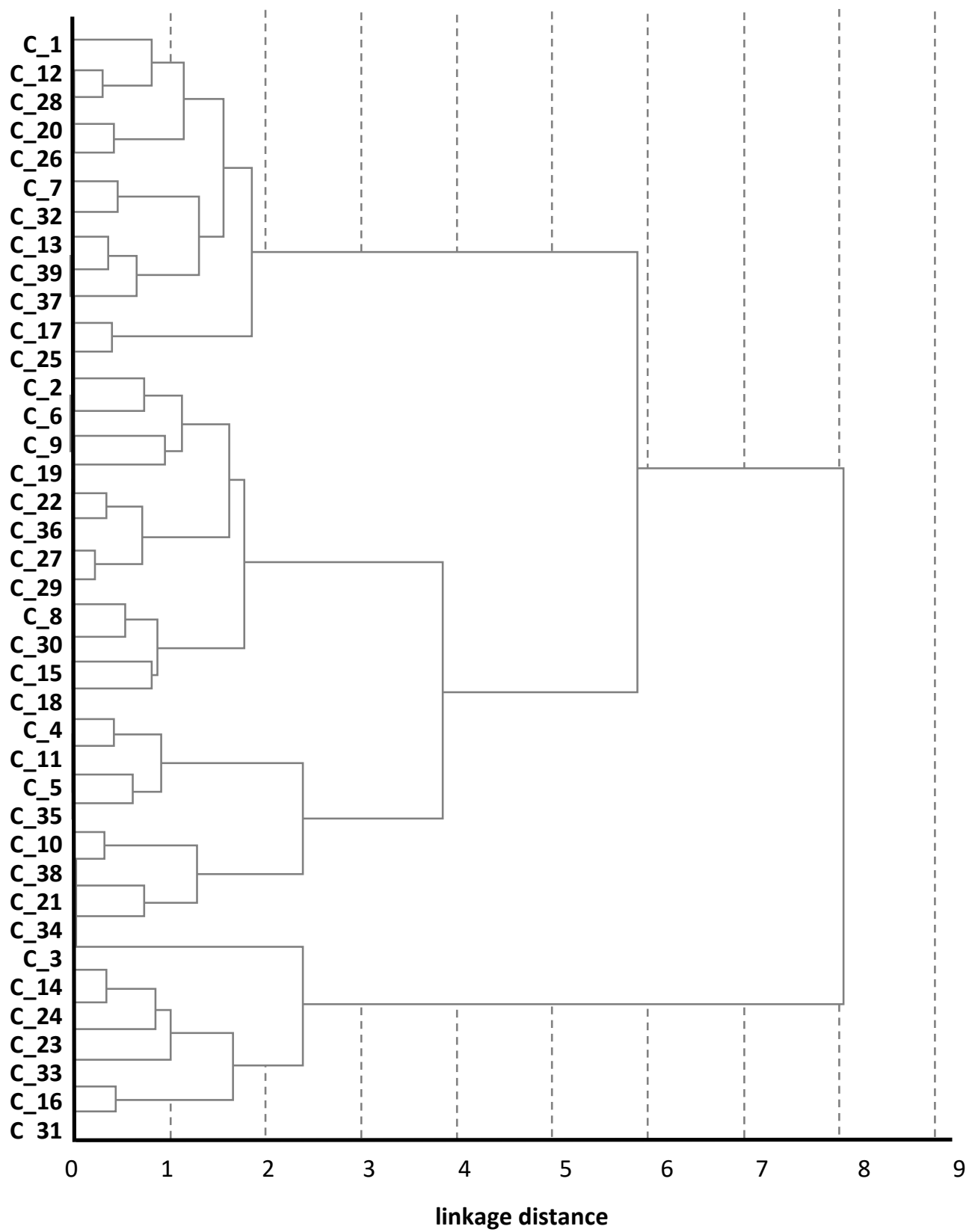

Figure 1. The Dendrogram of the Competences - Tree Diagram for 39 Cases, Ward's Method, Euclidean Distances (Authors'own Study based on the Results Obtained in Statistica Software)

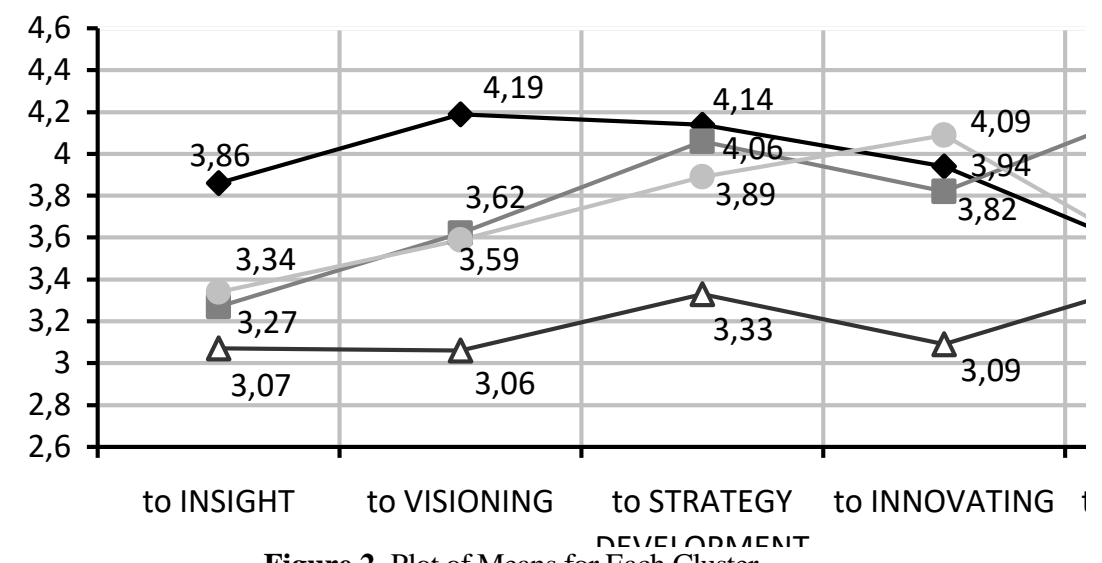

Figure 2. Plot of Means for Each Cluster

(Authors'own study based on the results obtained in Statistica software) 
Table 4

Clusters of Competences - Elements and the Distances from the Center of the Cluster (Own Elaboration)

\begin{tabular}{|c|c|c|}
\hline Number of cluster & Competence symbol & Distance from the center \\
\hline \multirow{13}{*}{1} & $\mathrm{C}_{-} 1$ & 0,299461 \\
\hline & C_2 & 0,196785 \\
\hline & C_7 & 0,313968 \\
\hline & C_9 & 0,183319 \\
\hline & C_15 & 0,195302 \\
\hline & C_16 & 0,289787 \\
\hline & C_20 & 0,181165 \\
\hline & C_24 & 0,374540 \\
\hline & C_27 & 0,318612 \\
\hline & C_31 & 0,318246 \\
\hline & C_32 & 0,155135 \\
\hline & C_34 & 0,148625 \\
\hline & C_38 & 0,351011 \\
\hline \multirow{11}{*}{2} & C_4 4 & 0,322051 \\
\hline & C_5 & 0,327343 \\
\hline & C__8 & 0,273139 \\
\hline & C_12 & 0,163591 \\
\hline & C_13 & 0,384465 \\
\hline & C_14 & 0,234038 \\
\hline & C_18 & 0,260516 \\
\hline & C_19 & 0,137069 \\
\hline & C_22 & 0,354561 \\
\hline & C_23 & 0,335638 \\
\hline & C_28 & 0,436071 \\
\hline \multirow{6}{*}{3} & C_3 & 0,393005 \\
\hline & C_11 & 0,640040 \\
\hline & C_21 & 0,205342 \\
\hline & C_30 & 0,203493 \\
\hline & C_37 & 0,243784 \\
\hline & C_39 & 0,263414 \\
\hline \multirow{9}{*}{4} & C_6 & 0,210153 \\
\hline & C_10 & 0,314685 \\
\hline & C_17 & 0,296824 \\
\hline & C_25 & 0,292691 \\
\hline & C_26 & 0,289807 \\
\hline & C_29 & 0,143520 \\
\hline & C_33 & 0,173106 \\
\hline & C_35 & 0,184159 \\
\hline & C_36 & 0,176827 \\
\hline
\end{tabular}

The authors made a juxtaposition of the scores for competences importance for a variable (dimension) for $a$ future-oriented entrepreneur in the competences clusters (table 5).

The highest scores for the variable were obtained in the first and the second cluster. The most important for $a$ future-oriented entrepreneur (table 5) are eleven competences from the second cluster (mean=4,35) and thirteen competences from the first cluster (mean=4,30). The scores are quite homogenous (coef.var $=3,14 \%$ and coef.var $=3,94 \%$ ). In the fourth cluster, there are nine competences which importance for a future-oriented entrepreneur are also high (mean $=4,04$ ), but heterogeneity of scores was a little bit greater (coef.var $=7,49 \%$ ) than in the remaining clusters. The least important are the competences from the third cluster (mean $=3,51)$. In this case the scores were quite homogenous (coef.var $=4,97 \%$ ).

On the basis of the correlation analysis it turned out that the dimensions most closely correlated with the assessment of competences in terms of their importance for the futureoriented manager are strategy development and visioning. On the basis of the results of cluster analysis, it is possible to recommend several sets of competencies depending on the criteria to be adopted. It is important to underline that the analysis of the whole set of competences resulted in the rejection of the third cluster of competences (covering competences C_3, C_11, C_21, C_30, C_37 and C_39). The competences form this cluster received low scores for the importance for a future-oriented manager and for the domains of his activity.

Table 5

The Juxtaposition of the Scores for Competences Importance for a Variable a Future-Oriented Manager in the Competences Clusters

\begin{tabular}{|c|c|c|c|c|c|c|}
\hline & \multicolumn{7}{|c|}{ Descriptive Statistics } \\
\cline { 2 - 7 } & Valid N & Mean & Min & Max & Std. Dev. & $\begin{array}{c}\text { Coef. } \\
\text { Var. }\end{array}$ \\
\hline CLUSTER 1 & 13 & 4,30 & 4,04 & 4,52 & 0,17 & 3,93 \\
\hline CLUSTER 2 & 11 & 4,35 & 4,13 & 4,57 & 0,14 & 3,14 \\
\hline CLUSTER 3 & 6 & 3,51 & 3,30 & 3,74 & 0,17 & 4,97 \\
\hline CLUSTER 4 & 9 & 4,04 & 3,57 & 4,57 & 0,30 & 7,49 \\
\hline
\end{tabular}

(source: Authors'own study)

Finally the authors posited one set of competences for the further analysis. It comprises average high marks for the importance for a future-oriented entrepreneur and at least 3 average high marks for the domains of his activity. Taking into account those criteria the list of the following 7 competences to be mastered by future-oriented entrepreneurs can be recommended:

- the ability to find and interpret weak signals of change and disruptions (wild cards and abnormal phenomena) (C_2);

- the ability to act proactively (autonomous strategic behaviour, enterprising spirit) (C_8);

- the ability to run strategic foresight within organization (C_15);

- the ability to manage change and uncertainty (C_18);

- the ability to create organisational vision (both collective and individual) (C_28);

- the ability to perceive unmet consumer needs (C_34);

- seeing the big picture (C_38).

The suggested set became the basis for further analyses. Finally, for the list of competences, that could be mastered by future-oriented entrepreneurs, fourteen competences were selected by juxtaposing: results of the cluster analysis, the internal assessment of the competences importance for a future-oriented entrepreneur, the external assessment of the competences importance for a future-oriented manager carried out during FEN meeting ${ }^{1}$ and ISPIM conference ${ }^{2}$ and comments to the competences provided both by internal and external experts. It should be noted that cluster analysis was a very important stage of the whole selection process, drawing attention to the competences important from the perspective of several equal dimensions.

\footnotetext{
${ }^{1}$ Spring 2017 FEN meeting in Turku following conference FUTURES OF A COMPLEX WORLD, (13-14 June 2017 - Turku, Finland) - a survey in the paper form was conducted

${ }^{2}$ XXVIII ISPIM Innovation Conference Composing the Innovation Sympony (1821 June 2017 - Vienna, Austria) - the ranking of the importance of the competences for a future-oriented manager/entrepreneur and a list of the competences posited by participants of the Futures literacy workshop
} 
Alicja Ewa Gudanowska, Anna Kononiuk, Katarzyna Debkowska. The Application of Cluster Analysis for the Selection ...

\section{Conclusions}

The theoretical contribution of the paper consist in presenting comprehensive methodology of cluster analysis applied for the determining the competences of future-oriented entrepreneurs. In the opinion of the authors, cluster analysis is a useful tool of grouping, but it should be juxtaposed with the qualitative assessment. In the case of the research presented in the article, the identified huge and diverse set of competences forced the authors of the research to conduct their initial selection and grouping, before applying the cluster analysis. Conducting a series of assessments and the necessity to narrow down the set of competences resulted in the fact that some of them, although very highly rated in the ranking resulting from a single evaluation and poorly rated in the others, were excluded.

In further research it would be worthwhile to look at such comments and deepen the research in their scope in order to explain such a large difference in the scores achieved by individual evaluations (e.g. risk taking capability - C_17). Coaching skills (C_11) and capacity for design thinking (C_26) proved to be interesting competences, to which further in-depth consideration could also be devoted. They were evaluated as low for a future-oriented entrepreneur, but at the same time, they were evaluated as very high for leadership and innovating.

Also an interesting observation could be made with the ability to look for products that provide real benefit (C_35). It was evaluated as high for a future-oriented entrepreneur, but at the same it obtained low marks for the fields of his/her activity which could indicate that one more domain in the analysis is needed (e.g. market orientation).

All in all, the cluster analysis conducted as part of the "Becoming Future-Oriented Entrepreneurs in universities and companies - beFORE" project enabled the authors to indicate the set of competences of future-oriented entrepreneurs, but also provided information on the possibilities of further research studies.

\section{Acknowledgments}

The preparation and publication of the article was carried out within WZ/WIZ/1/2019 project and was financed from Ministry of Science and Higher Education funds.

\section{References}

Association of Professional Futurists (2016). Foresight Competency Model - 1.1. Available from internet: http://apf.org/wordpress/wp-content/uploads/APF-Foresight-competency-model-1.1-1.pdf

Baskarada, S., Shrimpton, D., \& Ng, S. (2016). Learning through Foresight. Foresight, 18(4), 414-433. https://doi.org/10. 1108/fs-09-2015-0045

Bird, B. (1995). Towards a theory of entrepreneurial competency, Advances in Entrepreneurship, Firm Emergence and Growth, 2, 51-72.

Bolinska, M., Dykas, P., Mentel, G., \& Misiak, T. (2019). Demographic forecasts and volatility of investment rates vs. Labor productivity trajectories, Journal of Business Economics \& Management, 20(6), 1045-1063. https://doi.org/10. 3846/jbem.2019.10446

Boyatzis, R. E. (1982). The Competent Manager: A Model for Effective Performance. New York: Wiley.

Chandler, G. N., \& Jansen, E. (1992), The founder's self-assessed competence and venture performance, Journal of Business Venturing ,7(3), 223-236. https://doi.org/10.1016/0883-9026(92)90028-P

Cooper, B., \& Vlaskovits, P. (2013). The Lean Entrepreneur: How Visionaries Create Products, Innovate with New Ventures, and Disrupt Markets. New York: Wiley.

Coyne, S. (2016). Sustainable Leadership; Rewire Your Brain for Sustainable Success. White Paper, Routlege, Taylor and Francis Group.

Edwards-Schachtera, M., Garcia-Granero, A., Sanchez-Barrioluengo, M., Quesada-Pineda, H., \& Amara, N. (2015). Disentangling competences: Interrelationships on creativity, innovation and entrepreneurship. Thinking Skills and Creativity, 16, 27-39. https://doi.org/10.1016/j.tsc.2014.11.006

European Centre for the Development of Vocational Training (Cedefop). (2018). Insights into skill shortages and skill mismatch: learning from Cedefop's European skills and jobs survey. Cedefop reference series, No. 106, Publications Office: Luxembourg. Available from internet: https://www.cedefop.europa.eu/files/3075_en.pdf

Filipowicz, G. (2016). Zarzadzanie kompetencjami. Perspektywa firmowa i osobista. Warszawa: Wolters Kluwer.

Gheorghiua, R., Andreescu, L., \& Curaj, A. (2016). A foresight toolkit for smart specialization and entrepreneurial discovery, Futures, 80, 33-44. https://doi.org/10.1016/j.futures.2016.04.001

Gonzalez, J. A. M., \& Kobylinska, U. (2019). Influence of personal variables on entrepreneurial intention: A comparative study between Poland and Spain, Engineering Management in Production and Services, 11(1), 68-79. https://doi.org/10.2478/emj-2019-0005

Grim, T. (2009). Foresight Maturity Model (FMM): Achieving Best Practices in the Foresight Field, Journal of Futures Studies, 13(4), 69-80. 
Gudanowska, A. E., Prieto Alonso, J., \& Tormanen, A. (2018). What Competencies Are Needed in the Production Industry? The Case of the Podlaskie Region, Engineering Management in Production and Services, 10(1), 65-74. https://doi.org/10.1515/emj-2018-0006

Habegger, B. (2010). Strategic foresight in public policy: Reviewing the experiences of the UK, Singapore, and the Netherlands. Futures, 42(1), 49-58. https://doi.org/10.1016/j.futures.2009.08.002

Hartigan, J.A. (1975). Clustering algorithms. New York: Wiley.

Heinonen, S., \& Ruotsalainen, J. (2012). Toward the Age of Neo-Entrepreneurs. World Future Review, 4(2), $123-133$. https://doi.org/10.1177/194675671200400216

Hertle, C., Siedelhofer, C., Metternich, J., \& Abele, E. (2015). The next generation shop floor management - how to continuously develop competencies in manufacturing environments. Paper presented at the 23rd International Conference on Production Research, Manila, Philippines.

Hertle, C., Tischa, M., Klasa, H., Metternicha, J., \& Abelea, E. (2016). Recording Shop Floor Management Competencies - A Guideline for a Systematic Competency Gap Analysis. Procedia CIRP, 57, 625-630. https://doi.org/10. 1016/j.procir.2016.11.108

Inayatullah, S. (2008). Six pillars: futures thinking for transforming. Foresight, 10(1), 4-21. https://doi.org/10.1108/14636 680810855991

Jain, R. K. (2011). Entrepreneurial Competencies: A Meta-analysis and Comprehensive Conceptualization for Future Research. Vision: The Journal of Business Perspective, 15(2), 127-152. https://doi.org/10.1177/0972262911 01500205

Kinkel, S., Schemmann, B., \& Lichtner, R. (2017). Critical Competencies for the Innovativeness of Value Creation Champions: Identifying Challenges and Work-integrated Solutions. Procedia Manufacturing, 9, $323-330$. https://doi.org/10.1016/j.promfg.2017.04.021

Kononiuk, A. (2014). Foresight Maturity of Service and Manufacturing Enterprises. Scientific Papers of Silesian University of Technology, 1919(73), 211-223. Available from internet: http://www.woiz.polsl.pl/ znwoiz/z73/ Kononiuk\%20A.pdf

Kononiuk, A., Sacio-Szymanska, A., \& Gaspar, J. (2017). How Do Companies envisage the Future. Functional Foresight Approaches, Engineering Management in Production and Services, 9(2), 21-33. https://doi.org/10.1515/emj-20170028

Kowal, J., \& Roztocki, N. (2015). Job satisfaction of it professionals in Poland: does business competence matter? Journal of Business Economics \& Management, 16(5), 995-1012. https://doi.org/10.3846/16111699.2014.924988

Kubat M. Kompetencje zawodowe. Available from internet: https://wuplodz.praca.gov.pl/documents/58203/842291/Kompetencje\%20zawodowe.pdf/be54b81e-3773-43be-97bf78e293b5ad00?t=1406796121000

Kuusi, O., \& Hiltunen, E. (2001). The Signification Process of the Future Sign, Journal of Futures Studies, 16(1), 47-66.

Levitin, J. (2014). The Organized Mind: Thinking Straight in the Age of Information Overload, Dutton.

Lewrick, M., Omar, M., Raeside, R., \& Sailer, K. (2010). Education for entrepreneurship and innovation: Management capabilities for sustainable growth and success. World Journal of Entrepreneurship, Management and Sustainable Development, 6(1/2), 1-18. https://doi.org/10.1108/20425961201000001

Magruk, A. (2014). The most important stages of innovative management of the future in the foresight approach. Problemy Eksploatacji - Maintenance Problems, 2, 15-26.

McGuiness, S., Pouliakas, K., \& Redmond, P. (2017). How useful is the concept of skill mismatch? ILO, Geneva.

Morris, M. H., Webb, J. W., Fu, J., \& Singhal, S. (2013). A Competency-based perspective on entrepreneurship education: conceptual and empirical insights. Journal of Small Business Management, 51(3), 352-369. https://doi.org/10. $1111 /$ jsbm. 12023

Mosakowski, E. (1998). Entrepreneurial Resources, Organizational Choices, and Competitive Outcomes. Organization Science, 9(6), 625-643. https://doi.org/10.1287/orsc.9.6.625

Osagie, E. R., Wesselink, R., Blok, V., Lans, T., \& Mulder, M. (2016). Individual competencies for corporate social responsibility: A literature and practice perspective. Journal of Business Ethics, 135(2), 233-252. https://doi.org/10. 1007/s10551-014-2469-0

Popper, R. (2008). Foresight methodology. In L. Georghiou, C. J. Harper, M. Keenan, I. Miles \& R. Popper (Eds.). The handbook of technology foresight: concepts and practice (pp. 44-90), Cornwall: Edward Elgar Publishing.

Popper, R. (2008). How are foresight methods selected? Foresight, 10(6), 62-89. http://dx.doi.org/10.1108/ 14636680810918586

Ratcliffe, J., \& Ratcliffe, L. (2015). Anticipatory Leadership and Strategic Foresight: Five 'Linked Literacies'. Journal of Futures Studies, 20(1), 1-18. http://dx.doi.org/10.6531/JFS.2015.20(1).A1 
Alicja Ewa Gudanowska, Anna Kononiuk, Katarzyna Debkowska. The Application of Cluster Analysis for the Selection ...

Recommendation of the European Parliament and the Council of 18 December 2006 on key competences for lifelong learning (2006/962/EC). Available from internet: https://eur-lex.europa.eu/LexUriServ/LexUriServ.do?uri= OJ:L:2006:394:0010:0018:en:PDF

Rohrbeck, R. (2010) Corporate Foresight: Towards a Maturity Model for the Future Orientation of a Firm, Heidelberg and New York: Springer Series: Contributions to Management Science.

Ronstadt, R. (1987). The Educated Entrepreneurs: A New Era of Entrepreneurial Education is Beginning. American Journal of Small Business, 11(4), 37-53. https://doi.org/10.1177/104225878701100403

Spencer, L., \& Spencer, S. (1993). Competence at Work: Model for Superior Performance. New York: Wiley.

Tryon, R.C. (1939). Cluster Analysis. Ann Arbor, MI: Edwards Brothers.

van der Laan, L., \& Erwee, R. (2012) Foresight styles assessment: a valid and reliable measure of dimensions of foresight competence?. Foresight, 14(5), 374-386. http://dx.doi.org/10.1108/14636681211269860

Volpentesta, A. P., \& Felicetti, A. M. (2011). Competence Mapping through Analysing Research Papers of a Scientific Community. In L. M. Camarinha-Matos (Ed.). Technological Innovation for Sustainability. DoCEIS 2011. IFIP Advances in Information and Communication Technology, vol 349. Springer, Berlin, Heidelberg. https://doi.org/10. 1007/978-3-642-19170-1_4

The article has been reviewed.

Received in January 2020; accepted in December2020.

This article is an Open Access article distributed under the terms and conditions of the Creative Commons Attribution 4.0 (CC BY 4.0) License (http://creativecommons.org/licenses/by/4.0/). 